\title{
Enhancing Productivity and Production of Onion (Allium cepa L.) Through the use of Improved Varieties at North Western Zoze of Tigray, Ethiopia
}

\author{
Gebremedhn Gebretsadkan, Yohanes Gebremicael, Kiros Asgele, Eyasu Abebe, \\ Weldegerima Gebrelibanos, Yrgalem Tsehaye
}

Tigray Agricultural Research Institute (TARI)

Shire-Maitsebri Agricultural Research Center (SMARC)

\begin{abstract}
Field experiment was conducted to study the effect different varieties on yield, yield attributing character and postharvest storability of onion (Allium cepa L.) in Tselemti district, North western Zone of Tigray During 20072009off season time. Four improved onion varieties namly:Bombey red, Adama red, Nasik red \&Nafis including Shendi (imported from Sudan),were tested in Randomized Complete Block Design (RCBD) with four replications. Accordingly, treatments were assigned randomly to the experimental plot within a block. The results showed that the difference in variety had significant effect on all characters except the non-significant effect of variety on neck thickness and bulb diameter. Nasik red variety gave significantlyhighest in plant height, leaf number, leaf length bulb length and marketable bulb yield i.e $35588 \mathrm{~kg} / \mathrm{ha}$ that exhibited $18 \%$ and $36 \%$ advantages on the dominantly produced varieties bombey red and adama red respectively.The overall study revealed that growing Nasik red variety is not only significantly increased the marketable bulb yield, but also better shelf life. Therefore, it is recommended for onion producers of Tselemti wereda for profitable onion yield
\end{abstract}

Key words-Onion, Storability, Variety, Yield.

\section{INTRODUCTION}

Onion (Allium cepa L.) is an important bulb crop, belonging to the family Alliaceae (Hanelt,1190).It is one of the most important and popular bulb crops cultivated commercially in nearly most parts of the world. Onions as food, medicine and religious object were known during the first Egyptian dynasty (3200 B.C.) (Ray and Yadav, 2005). ). It is important in the daily diets of human's in worldwide and
Ethiopians as well (MoARD, 2006). Onion contributes significant nutritional value to the human diet and are primarily consumed for their distinctive flavor widely used in soups, meat dishes, salads, food dressings and sandwiches, medicinal purposes and is cooked alone as a vegetable. Its pungency is due to the presence of a volatile oil (Allyl propyl disulphide) (Malik, 1994).

Onion (Allium cepa L.) is a recently introduced bulb crop in the agriculture commodity of Ethiopia and it is rapidly becoming a popular vegetable among producers and consumers (Lemma and Shimeles, 2003; Dawit et al., 2004). It is more widely grown in Ethiopia for local consumption and for flower export (Lemma and Shimeles, 2003). It is valued for its distinct pungency or mild flavour and also consumed universally in small quantities and used in many homes almost daily, primarily as a seasoning for flavouring of dishes, sauces, soup, and sandwiches in many countries of the world (Geremew et al., 2010).

Onion is one of the most important vegetable crops in Ethiopia which is used almost daily as a spice and vegetable in the local dish regardless of religion, ethnicity, and culture (CSSE, 2006). The diverse agro-climatic conditions that prevail in the country provide the opportunity of producing onion bulb, seeds and cut flower for local use and export market (CSSE, 2006). Additionally, its higher yield potential, availability of desirable cultivars for various uses, ease of propagation by seed, high domestic (bulb and seed) and export (bulb, cut flowers) markets in fresh and processed forms is making the crop increasingly important in Ethiopia (Yohannes,1987).

Ethiopia has enormous potentials to cultivate the vegetable crops at small as well as large commercial scale. The 
country has high potential to benefit from onion production, and the demand for onion is increasing from time to time for its high bulb yields, seed and flower production potential (Lemma and Shimelis, 2003).Statistics indicated that, the production of onion in Ethiopia during $2012 / 2013$ growing season was in about 21865 ha of land yielding a total production of 219919 tons with an average yield (10.06 tons /ha) which is too low as compared to the world average of 19.31 tons/ha (FAOSTAT,2013).

There are a number of constraints that cause low productivity of onion in Ethiopia. The low yield of onion in the country is reported to be due to low fertility of soil, inappropriate fertilizer rate, lack of improved varieties, and poor management practices (Lemma and Shimelis, 2003).

The use of proper agronomic practice has an undoubted contribution in increasing crop yield. The optimum level of any agronomic practice like plant spacing, plant population, planting date, harvesting time can bring desired results. The optimum use of spacing or plant population has dual advantages. It also avoids strong competition between plants for growth factor such as water, nutrient and light. Conversely,optimum plant population enables efficient use of available crop land without wastage (Zubelidia and Gases, 1977).

The use of appropriate agronomic management practices is important to increase the productivity and production of the crop. However, in the country, intra-row spacing of 10 $\mathrm{cm}$ and inter-row spacing of $20 \mathrm{~cm}$ during transplanting to permanent field is used which was recommended before 20 years (FAO, 1995). But, plant spacing as an important economic consideration in the production of onion should have to depend on type of variety (plant architecture, growth habit etc.), agro-ecology, production system etc. Therefore, for onion production, it is very difficult to give general recommendation to be applied uniformly in all agro ecologies of the country (UAAIE, 2001). Gupta et al. (1994) and Lemma and Shimeles (2003) suggested that to optimize onion productivity, full package of information is required for each growing region of the country.

Similarly, the success of onion production is also depend on soil nutrients. Different levels of nutrients affect the yield and taste of the bulbs even within a variety.Application of nutrients play a major role in increasing productivity of onion. Onions are weaker than most other crop plants in extracting nutrients from the soil, especially the immobile types because of their shallow and unbranched root system; hence they require and often respond well to addition of fertilizer (Brewster, 1994). Nitrogen and phosphorus are often referred to as the primary macro nutrients because of the probability of plants being deficient in these nutrients and because of large quantities taken up from the soil relative to other essential nutrients(Marschner, 1995).

Generally, there are a number of constraints that cause low productivity of onion in Ethiopia. The low yield of onion in the country is reported to be due to low fertility of soil, inappropriate fertilizer rate, lack of improved varieties, and poor management practices (Lemma and Shimelis, 2003). Among these constraints, inappropriate use of mineral fertilizers, lack of improved and adaptable varieties and un proper plant spacing are the most limiting factors in our mandate areas.

Therefore the present study was conducted with general objectives of identifying adaptable onion varieties, assessing the effects of nitrogen and phosphorus fertilizer rates and different inter and intra row spacing on growth, yield and yield components of onion in the study area.

\section{Objective}

To investigate the performance of different varieties of onion \& identify the best agro ecologically adaptive, high yielder and disease resistance onion varieties to the area

\section{METHODOLOGY}

The experiment was conducted at Tselemti Wereda ShireMaitsebri (SMARC) experimental Station during 20072009E.c off season periods. Four improved onion varieties namly: Bombeyred, Adamared, Nasik red \& Nafis including Shendi (imported from Sudan), were evaluated for their yield performance for the last three years. The field experiment was laid out in Randomized Complete Block Design (RCBD) with four replications. Accordingly, treatments were assigned randomly to the experimental plot within a block.

A plot size of $2 \times 3 \mathrm{~m}\left(6 \mathrm{~m}^{2}\right)$ was used. The blocks were separate by $1.5 \mathrm{~m}$, whereas plots within a block were $1 \mathrm{~m}$ apart from each other. Each plot consists of 5 rows of $3 \mathrm{~m}$ length, with a spacing of $40 \mathrm{~cm}$ between rows \& $10 \mathrm{~cm}$ between plants. Recommended amount of fertilizer $(200 \mathrm{~kg} / \mathrm{ha}$ DAP \& $100 \mathrm{~kg} / \mathrm{ha}$ Urea $)$ were used. All management practices (ploughing, cultivation, watering, nursery and transplanting method, weeding and others) were applied uniformly to all plots as per standard recommendations for the crop. The experimental area was kept weed free by hand pulling throughout the cropping season. In addition to the field evaluation, simple postharvest evaluation also conducted for all the varieties. For this purpose $6 \mathrm{~kg}$ representative bulbs were selected from each 
variety and kept under normal storage condition to compare their storability.

\section{Method of Agronomic Data Collection}

All data relating to yield and yield components were collected from the central three rows by excluding plants from either end of the rows. For the purpose of crop data collection two (2) plants/row or six(6) plants/plot were selected randomly from each plot and observations on growth, yield and yield components of the crop such as: plant height, average leaf length, average leaf number, average neck thickness, average bulb length, diameter \&yield were recorded.

Plant height (cm): Plant height was measured from the ground level up to the tip of the

Longest leaf using ruler. Plant height of sex randomly selected plants were measured in the

central rows of each plot at physiological maturity stage of the crop and the average was

Computed.

Days to physiological maturity: It was registered on plot basis as the actual number of days from date of transplanting to when about $75 \%$ of the leaves fell down and $2 / 3$ leaves had turned yellow

Number of leaves per plant: The number of fully developed leaves of six randomly selected plants was counted at the active green leaf stages and the average was computed to obtain number of leaves per plant.

Leaf length $(\mathbf{c m})$ : Leaf length was recorded as the average length of the longest leaves in six randomly selected plants at maturity.

Bulb diameter (cm): Bulb diameter was measured at right angles to the longitudinal axis at the widest circumference of the bulb of six randomly selected plants in each plot using veneer calliper (Saud et al., 2013) at harvest.

Bulb length (cm): Bulb length was the vertical average length of the matured bulb of six randomly selected plants in each plot which was measured by veneer calliper.

Bulb neck thickness (cm): The average neck thicknesses of six randomly selected plants in each plot were obtained by measuring the neck of bulbs at the narrowest point at the junction of bulb and leaf sheath using a veneer calliper.

Marketable bulb yield (t /ha): Marketable bulb yield was determined after discarding the unmarketable bulb, weight healthy bulbs and having nationally accepted marketable bulb weight of $60 \mathrm{~g}$ (Tegbew, 2011) at harvest in each plot and converted to $\mathrm{t} / \mathrm{ha}$.

For postharvest evaluation six $\mathrm{kg}$ of onion from each variety were weighed and stored in a conventional storage room. Weight loss and number of sprouted bulbs were recorded in every two weeks for about 3months, then finally at the end of the $3^{\text {rd }}$ month weight and number of un sprouted bulbs were recorded and tried to compare the storability of each variety.

\section{Method of Data Analysis}

All crop data collected in this study were subjected to two way statistical analysis of variance (ANOVA) following a procedure appropriate to a randomized complete block design as suggested by (Gomez and Gomez, 1984). When the treatment were significant, least significance differences (LSD) by Dunken's multiple range comparison were used for mean separation at $\mathrm{p}=0.05$.

\section{RESULTS \& DISCUSSION}

The data in (Table 1\&2)showed a significant $(\mathrm{p}<0.05)$ variability between the varieties in most of the traits.

\section{Days to Bulb Maturity}

Days to maturity was significantly $(\mathrm{P}<0.05)$ influenced by variety. Bombay Red and Shendi matured significantly earlier than the other varieties at about $124.9 \& 127$ and the next variety at about 134.2 days, whereas Nasik variety matured in about 16.8 days later than Bombey red (Table 1). The variation of maturity among onion varieties might be due to their genetic differences. Bombay Red variety was found to be the earliest, which matured 23 days earlier than Adama Red followed by Melkam which was earlier by 18 days than the Adama Red (Yemane et al., 2014).Similarly Azoom et al. (2014) also reported significant differences among eight onion varieties for days to bulb maturity. Bombay Red and Adama Red matured by less than 120 or/and in between 110 to 130 days, respectively (EARO, 2004).

\section{Leaf Length}

The analysis of variance revealed a significant $(\mathrm{P}<0.05)$ effect of variety on leaf length. Both Nasik Red and Adama red showed the highest mean leaf length $(40.27 \mathrm{~cm} \&$ $39.25 \mathrm{~cm}$ ) .Nasik red had significantly higher leaf length by about $12.2 \%$ than Bombay Red(currently dominant variety in the testing area (Table-1). The difference of varieties in leaf length might be due to their differences in genetic makeup. In agreement with the current result, Yemane et al. (2014) reported that Adama Red $(40.75 \mathrm{~cm})$ showed higher leaf length than Melkam (37.83 cm) and Bombay Red (35.17 cm). Similarly, Mondal et al. (1986), Ghafoor et al. (2003) and Jilani et al. (2010) also reported the differences among cultivars with respect to leaf length. 


\section{Plant height}

The analysis of variance showed that plant height was significantly $(\mathrm{P}<0.05)$ affected by Variety. The plant heights of Nasik red, Nafis and Adama red varieties attained maximum height of $(45.9,45.25 \& 42.9 \mathrm{~cm})$ respectively, which was significantly different than Bombay Red and Shendi variety(Table-1).

Although they have grown in the same environment the difference in plant height among the onion varieties could be due to the difference in their genetics make up that was differently influenced by the environment. Tegbew (2011) indicated the mean plant height of Adama Red $(62.25 \mathrm{~cm})$ cultivar was significantly higher than Bombay Red (56.04 $\mathrm{cm})$ cultivar. The result was similar to the finding of Ghafoor et al. (2003) and Yemane et al. (2014) who indicated the presence of significant differences among onion cultivars in plant height.

Table.1: Effect of variety on days to maturity, plant height, number of leafs per plant and leaf length of onion

\begin{tabular}{|l|l|l|l|l|l|}
\hline S/N & Variety & DM & Pht $(\mathbf{c m})$ & ALN & ALL(cm) \\
\hline 1 & Nasik red & $141.7 \mathrm{c}$ & $45.90 \mathrm{a}$ & $10.881 \mathrm{a}$ & $40.27 \mathrm{a}$ \\
\hline 2 & Shendi & $127.0 \mathrm{a}$ & $37.16 \mathrm{~b}$ & $8.456 \mathrm{c}$ & $33.56 \mathrm{c}$ c \\
\hline 3 & Bombey red & $124.9 \mathrm{a}$ & $30.23 \mathrm{c}$ & $8.920 \mathrm{bc}$ & $28.08 \mathrm{~d}$ \\
\hline 4 & Nafis & $134.2 \mathrm{~b}$ & $45.25 \mathrm{a}$ & $10.057 \mathrm{abc}$ & $39.52 \mathrm{ab}$ \\
\hline 5 & Adama red & $140.9 \mathrm{c}$ & $42.90 \mathrm{a}$ & $10.599 \mathrm{ab}$ & $36.69 \mathrm{bc}$ \\
\hline Mean & $\mathbf{1 3 3 . 7 3}$ & $\mathbf{4 0 . 2 9}$ & $\mathbf{9 . 7 8}$ & $\mathbf{3 5 . 6 2}$ \\
\hline CV $(\boldsymbol{\%})$ & $\mathbf{3 . 4}$ & $\mathbf{1 2 . 7}$ & $\mathbf{2 0 . 2}$ & $\mathbf{1 1 . 0}$ \\
\hline LSD & $\mathbf{6 . 4 0 2}$ & $\mathbf{7 . 3 0 9}$ & $\mathbf{2 . 8 1 6}$ & $\mathbf{5 . 5 9 4}$ \\
\hline
\end{tabular}

;Means with in the same column followed by the same alphabets do not differ significantly at the $5 \%$ level of significance:DM=Days to maturity;pht=plant height;ALN=Average leaf number;ALL=Average leaf length;

\section{Marketable bulb yield}

The variety had significant effect $(\mathrm{P}<0.05)$ on marketable bulb yield. Nasik red had significantly higher marketable bulb yield $(35588 \mathrm{Kg} / \mathrm{ha})$ than Bombay Red and Adama which are the commonly produced varieties in the area (Table-2). A cultivar may performs differently under diverse agro-climatic conditions and various cultivars of the same species grown even at the same environment with different management often yield differently due to the genetic makeup of the cultivars and the interaction effects of genotype $\mathrm{x}$ environment or genotype $\mathrm{x}$ management (Yemane et al., 2013). Gautam et al. (2006) indicated that yield of fresh onion bulb was significantly affected by varieties.In agreement with this finding Rajcumar (1997), Jilani (2004) and Geremew et al. (2010) also reported significant difference within varieties for marketable bulb yield in onion.

Table.2: Effect of variety on Bulb diameter, Bulb length, Neck thickness and Marketable yield of onion

\begin{tabular}{|l|l|l|l|l|l|}
\hline $\mathbf{S} / \mathbf{N}$ & Variety & ANT(cm) & ABL(cm) & ABD(cm) & MY(Kg/ha) \\
\hline 1 & Nasik red & 1.424 & $5.546 \mathrm{a}$ & 5.816 & $35588.0 \mathrm{a}$ \\
\hline 2 & Shendi & 1.207 & $5.674 \mathrm{a}$ & 5.992 & $26119.6 \mathrm{~b}$ \\
\hline 3 & & & & 6.039 & $30005.1 \mathrm{ab}$ \\
\hline 4 & Nafis & 1.323 & $4.899 \mathrm{~b}$ & 5.863 & $26362.6 \mathrm{~b}$ \\
\hline 5 & Adama red & 1.319 & $5.637 \mathrm{a}$ & 5.586 & $26099.4 \mathrm{~b}$ \\
\hline Mean & & $\mathbf{1 . 3 1 9}$ & $5.436 \mathrm{a}$ & $\mathbf{5 . 8 5 9}$ & $\mathbf{2 8 8 3 . 9 4}$ \\
\hline CV $(\%)$ & $\mathbf{2 7 . 3}$ & $\mathbf{5 . 4 3 8}$ & $\mathbf{7 . 6}$ & $\mathbf{2 7 . 4}$ \\
\hline
\end{tabular}

ANT=Average neck thickness; $A B L=$ Average bulb length; $A B D=$ Average bulb diameter; $M Y=$ Marketable yield 


\section{Postharvest performance of the varieties}

In addition to the agronomic performance simple postharvest evaluation was also carried out to evaluate the storability potential of each variety. For this purpose similar amount (weight) of onion from each variety was store for three months at a normal room temperature and the trial was repeated for two (2) years. Data like Number of sprouted bulbs, Weight of non -sprouted bulbs, Total weight loss e.t.c was recorded in every two weeks for about three months. The mean result showed that, there was a big difference in weight loss among the different onion varieties (Tabel-3\&4).Maximum weight loss of (100\%)\& 97\% was recorded at Adama red in the $1^{\text {st }}$ and $2^{\text {nd }}$ year respectively followed by bombey red. Among the tested varieties minimum weight loss

Was recorded from shendi. $60 \%$ in the $1^{\text {st }}$ year and $40 \%$ in the seconder were loss from the total initial weight in the three month period. This indicates that varietal difference have a great role in the postharvest and quality of onion bulbs (Table-5\&6).

Table.3: simple postharvest performance of the different onion varieties (2007 cropping season)

\begin{tabular}{|c|c|c|c|c|c|c|c|c|}
\hline \multirow[t]{2}{*}{$\mathbf{S} / \mathbf{N}$} & \multirow[t]{2}{*}{ Variety Name } & \multirow{2}{*}{ 至咅 } & \multirow{2}{*}{ 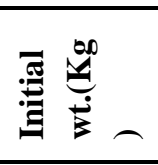 } & \multicolumn{3}{|c|}{$z+Z 0=n=: 0 \equiv$} & \multirow{2}{*}{ 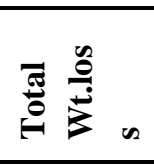 } & \multirow{2}{*}{ 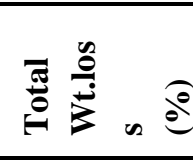 } \\
\hline & & & & $\rightarrow$ os & $N \Xi \Sigma$ & $I_{m}$ & & \\
\hline 1 & Shendi & 43 & 3.5 & 2.5 & 1.8 & 1.4 & 2.1 & 60 \\
\hline 2 & Nafis & 38 & 3.5 & 2.7 & 1.4 & 0.29 & 3.21 & 92 \\
\hline 3 & Adama red & 47 & 3.5 & 2.7 & 0.89 & - & 3.5 & 100 \\
\hline 4 & Nasik red & 43 & 3.5 & 2.9 & 1.4 & 0.4 & 3.1 & 88.5 \\
\hline 5 & Bombey red & 55 & 3.5 & 2 & 0.53 & 0.1 & 3.4 & 97 \\
\hline
\end{tabular}

Table.4: simple postharvest performance of the different onion varieties (2008 cropping season)

\begin{tabular}{|c|c|c|c|c|c|c|c|c|}
\hline \multirow[t]{2}{*}{$\mathbf{S} / \mathbf{N}$} & \multirow[t]{2}{*}{ Variety Name } & \multirow{2}{*}{ 至 } & \multirow{2}{*}{ 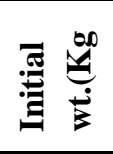 } & \multicolumn{3}{|c|}{$z+Z \circ=$ के $0 \equiv 000$} & \multirow{2}{*}{ 至 } & \multirow{2}{*}{ 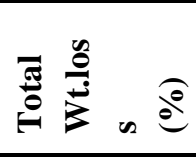 } \\
\hline & & & & $-\infty \in \sum$ & $N \Xi \Sigma$ & $\Xi_{n} \sum$ & & \\
\hline 1 & Shendi & 70 & 6 & 5.05 & 4.54 & 3.58 & 2.42 & 40 \\
\hline 2 & Bomboy red & 62 & 6 & 5.35 & 4.56 & 2.03 & 3.97 & 66 \\
\hline 3 & Adama red & 63 & 6 & 4.316 & 1.701 & 0.545 & 5.455 & 90 \\
\hline 4 & Nasik red & 56 & 6 & 4.95 & 3.995 & 1.307 & 4.693 & 78 \\
\hline 5 & Nafis & 60 & 6 & 4.2 & 2.28 & 0.88 & 5.12 & 85 \\
\hline
\end{tabular}

IV. SUMMARY AND CONCLUSION

Onion is widely recognized as an important vegetable condiment as a form of dry bulb and cash crop in Ethiopia. It is successfully produced under rained as well as irrigated conditions in different agro ecologies of the country by small holder farmers and commercial growers. However, the productivity of onion is not as expected due to many production constraints. The use of lower yielder and un adaptable varieties is among the many production constraints. So, selection of varieties that produce high yield is very critical to improve the yield of onion.Therefore; this study was conducted to evaluate the agronomic and postharvest performance of five onion varieties. The experiment was conducted at Shire-Maitsebri Agricultural Research center, Tselemtiworeda, North western Zone of Tigray during 2007-2009 under irrigation. The experiment was laid out in randomized complete block design (RCBD) with four replications. Data were collected for phenology of the crop, growth, yield and yield components and analyzed accordingly.

The analysis of variance revealed the significant effect of variety on all the parameters exceptneck thickness and bulb diameter. Nasik red variety had superior plant height, Leaf number, leaf length, bulb diameter and marketable bulb yield than the other tested varieties. Nasik red had higher marketable bulb yield by about $18 \%$ \& $36.35 \%$ than the dominantly produced bombey red and Adama red varieties respectively.

Regarding to the postharvest performance of the onion varieties, Minimum weight loss was recorded from Shendi variety followed by Nasik red variety. Total weight loss at 
the end the three month storage was recorded from the commonly produced varieties.

\section{REFERENCES}

[1] Azoom, A.A.A., Zhani, K. and Hannachi, C. 2014. Performance of eight varieties of onion (Allium cepa L.) cultivated under open field in Tunisia open field in Tunisia. NotulaeScientiaBiologicae, 6(2): 220-224.

[2] Brewster, J.L. 1994. Onions and other vegetable Alliums. CABI Publishing, Wallingford, United Kingdom. 236p.

[3] CSSE (Crop Science Society of Ethiopia). 2006. Farmers' participatory onion seed production in the Central Rift Valley of Ethiopia: achievement, constraints and its implication for the national seed system. Conference summary, The Conference of the Crop Science Society of Ethiopia, Addis Abeba, Ethiopia.

[4] DawitAlemu, AberaDeressa, Lemma Desalegn and ChemdoAnchala. 2004. Domestic vegetable seed production and marketing. Research report. No 57. EARO, Addis Ababa, Ethiopia.

[5] EARO (Ethiopia Agricultural Research Organization). 2004. Directory of released crop varieties and their recommended cultural practices. Ethiopian Agricultural Research Organization Addis Abeba, Ethiopia

[6] FAOSTAT (Food and Agriculture Organization Statistics). 2013. Food and Agriculture Organization StatisticsDatabase,Agriculturalproductionindices.Rom e,Italy.DOI:http://www.faostat3.fao.org/download/Q/ QC/E (Accessed 21 July 2015).

[7] Gautam, I.P., Khatri, B. andPaudel, G.P. 2006. Evaluation of different varieties of onion and their transplanting times for off-season production in Mid Hills of Nepal. Nepal Journal of Agriculture Research, 7: 21-26

[8] GeremewAwas, TeshomeAbdisa, KasayeTolesa and AmentiChali. 2010. Effect of intra- row spacing on yield of three onion (Allium cepa L.) varieties atAdami Tulu Agricultural Research Center (Mid rift valley of Ethiopia). Journal of Horticulture and Forestry, 2(1): 007-011.

[9] Ghaffoor, A., Jilani, M.S., Khaliq, G. and Waseem, K. 2003. The effect of different NPK levels on the growth and yield of three onion (Allium cepa L.) varieties. Asian Journal of Plant Sciences, 2: 342-346.
[10] Gupta, R.P., Srivastava, K.J., Pandey, U.B. and Midmore D.J. 1994. Diseases and insect pests of onion in India. Acta Horticulture, 358: 265-372

[11] HaneltP(1990) Taxonomy,Evolution and History in onions and Allied crops,edited by Harim D. Rabinowitch and Jams L.Browster.

[12] Jilani, M.S., Ahmed, P., Waseem, K. and Kiran, M. 2010. Effect of plant spacing on growth and yield of two varieties of onion (Allium cepa L.).Pakistan Journal of Science, 62(1): 37-41.

[13]Lemma Dessalegn and ShimelesAklilu. 2003. Research Experience in Onion Production.

[14] Marschner, H. 1995. Mineral nutrition of higher plants.Academic Press.London.Saud, S., Yajun, C., Razaq, M., Luqman, M., Fahad, S., Abdullah, M. and Sadiq, A. 2013. Effect of potash levels and row spacing on onion yield. Journal of Biology Agriculture and Health care, 3(16): 2013-2118.

[15] Mondal, M.F., Brewster, J.L. Morris, G.E.L and Butler, H.A. 1986. Bulb development in onion (Allium cepa L.). Effects of the size of adjacent plants. Shading by neutral and leaf filters, irrigation and nitrogen regime and the relationship between the red and far red spectral ratio in the canopy and leaf area index. Annuals of Botany, 58: 207-219.National crop improvement conference. 22-26, April 1988, Institute of Agricultural Research, Addis Abeba, Ethiopi

[16] Rajcumar, R. 1997. Selection of onion cultivars for yield, early maturity and storage potential in Mauritius. Food and Agricultural Research Council, Reduit, Mauritius. pp. 153-159.

[17]Ray, N. andYadav, D.S. 2005. Advance in vegetable production. Research book center. New Delhi. pp. 237-238.Research Report Number, 55, EARO, Addis Ababa, Ethiopia.

[18] TegbewWalle. 2011. Yield and yield components of onion (Allium cepa Var. cepa) Cultivars as influenced by population density at BirSheleko, North-Western Ethiopia. MSc Thesis, Haramaya University, Haramaya, Ethiopia.

[19] UAAIE (Upper Awash Agro-Industry Enterprise). 2001. Progress Report 1996-2002, Addis Ababa, Ethiopia. Agricultural product 2001/2002, Addis Ababa, Ethiopia.

[20] YemaneKahsay, DerbewBelew and Fetien Abay. 2014. Effect of intra-row spacing on plant growth and yield of onion varieties (Allium cepa L.) at 
Aksum, Northern Ethiopia. African Journal of Plant Science, 9(10): 931-940.

[21] YohannesAbebe. 1987. Current activities, recommendation and future strategies of onion research in Ethiopia. pp. 358-370. In: Burba, J. L., and C.R., Galmarini (eds), 1994. Proceedings of the $19^{\text {th }}$

[22]Zubeldia., A. and J. L. Gases, 1977. The effect of spacing and number of stem on the earliness and total yield of tomato cultivars. Production vegetable.FAO (Food and Agricultural Organization). 1995. Production yearbook. Food and Agriculture Organization of the United Nations, Rome, Italy. 